\title{
The Effectiveness of Teachers' Higher Order Thinking Skills Questions on Science Test Achievement of form Four Students
}

\author{
Sheela Kumari A/P Appanna, Tajularipin Sulaiman \\ Universiti Putra Malaysia, 43400 UPM, Serdang Selangor, Malaysia \\ Corresponding e-mail: tajulas@upm.edu.my
}

\begin{abstract}
This quasi-experimental study aims to investigate the effectiveness of teacher's higher order thinking skills questions on test achievement of form four students. Sixty (60) students from intact groups were assigned into the control and treatment groups. The treatment group were exposed to teacher's higher order thinking skills questions and the control group with routine teaching. Varies higher order thinking skills questions were incorporated into ten lessons (one hour thirty minutes per lesson) in the treatment group and the treatment lasted for five weeks. The instrument used in this study was a Science Test for Higher Order Thinking Skills (SciTHOTS). The SciTHOTS consists of two parts which are Section A, objective questions and Section B, subjective questions. The SciTHOTS was developed based on higher order thinking skills questions which consist of three higher cognitive domains; analysing, evaluating and creating. The SciTHOTS was used as pre-test and post-test for control and treatment groups. The reliability of the SciTHOTS for section A is 0.79 and for section B is 0.83 . Descriptive statistics and analyses of independent sample t-test were used to analyse data to answer the research questions. The findings show that there is a significant difference between the mean post-test scores of the control and treatment groups in the SciTHOTS. There was also a significant difference between the mean post-test scores of control and treatment groups for each cognitive domain; analysing, evaluating and creating in the SciTHOTS. The results revealed that students from the treatment group performed better than control group in SciTHOTS. This showing that students could answer questions of higher order thinking skills better when they were exposed to teacher's higher order thinking skills questions during classroom instructions.
\end{abstract}

Keywords: higher order thinking skills, questions, science test

\section{INTRODUCTION}

Higher Order Thinking Skills (HOTS), such as critical thinking, logical thinking, and reasoning skills are the basic skills for daily life to survive in the global market. Therefore, national policy makers and educators around the world have a great desire to identify some factors and understand what may have meaningful effect on the students' higher order thinking skills. Today, the main purpose of our educational system is to teach students how to apply the knowledge of science in daily life in many contexts. The students' achievements particularly in science both of national assessments and international assessments which includes questions on higher order thinking skills are becoming a guideline for the educational policy makers and for the education system.

In order to increase the students higher order thinking skills, teachers' questions on higher order thinking skills may play a major role in classroom instruction. The teachers' questioning in classroom have been used for centuries as a tool to assess students' knowledge, promote comprehension and to develop higher order thinking skills among students (Tofade, Elsner \& Haines, 2013). Instructional questions promote students' cognitive processes at different levels and complexity (Bloom, 1956). 
Science classroom instruction becomes a major field to be explored due to international assessment findings such of TIMSS trends that showed students of the most secondary school in Malaysia performing at less than satisfactory levels continuously, particularly, in tasks that are cognitively demanding (Tajudin \& Chinappan, 2016). There is a need to prepare the new generation with higher order thinking skills as a necessity for lifelong learning and to compete in the global job market. Developing students with critical and creative thinking has become an important component of education curriculum (Malaysia Education Blueprint 2013-2015, E-10). Therefore, teachers are urged to find the best ways and provide opportunities for students' deep thinking in classroom practices.

The teachers questioning can be an essential tool and practical means for the teachers to develop higher order thinking skills among students. A research has shown that students' understandings and thinking about science can be enhanced when teachers facilitate an interactive discourse through classroom questioning (Chin, 2006). Furthermore, a research on teachers questioning; strategies, practices, approaches and application of frameworks for integrating higher order thinking has been widely studied, however the types of questions pose by teachers (Ong, Hart \& Chen, 2016) and the effect on students' higher order thinking skills in science remain under-explored.

On the other hand, the teacher questioning can be a useful and practical means for teachers to work towards the goal of developing higher order thinking skills among students. Those teachers' questions can be a frequent component of classroom instruction and they play an important role in determining the nature of discourse during science instruction (Chin, 2007). The kind of questions that teachers ask can influence the type of cognitive processes that students engage in the process of constructing scientific knowledge.

A research has shown that students' conceptual understandings in science are developed within social contexts in the classroom, and their understandings and thinking about science can be enhanced when teachers facilitate an interactive discourse through classroom questioning (Chin, 2007). Meta-analysis of twenty studies by Redfield and Rousseau's (1981) on the relationship between teacher questioning and student achievement showed that 'students' achievement gains are expected with higher level cognitive questions assuming a primary role during classroom instructions." Redfield and
Rousseau (1981) believe that teachers' questioning of students is an important variable in student achievement.

Thus, studying on what kind of questions teachers ask and the effect on students' achievement will give an insight to educators in planning their classroom instructions. Some researchers' findings show that higher order thinking skills questions elicit deeper and critical thinking (Tofade, Elsner \& Haines, 2013). However, the scenario in the classrooms are different, the purpose of teacher questioning in traditional lessons is to evaluate what students know. The teacher asks a closed question that requires a short answer and is basically information-seeking, usually fixed at the recall or lower-order cognitive level (Chin, 2007). Teachers usually ask convergent questions, lower-order questions that rely on students' factual recall of prior knowledge rather than asking divergent questions, higher order questions that requiring students to analyse and evaluate concepts and promote deep thinking. (Tofade, Elsner \& Haines, 2013).

Research study has stated that cognitive opportunities such as analysing, evaluating, solving problems, give logical reasoning and making rational judgements can be promoted by higher order questions (Chen, 2016). The teachers questioning which focus on higher order thinking skills will be able to prepare students with cognitive skills that able them to think creatively, critically and apply logical reasoning in various settings.

This study attempts to investigate whether there is an effect on students' higher order thinking skills when they were posed with higher order thinking skills' questions by teacher during science classroom instructions. The students' higher order thinking skills will be measured using SciTHOTS before (pre-test) and after treatment (post-test) for both control and treatment groups. It also attempts to explore in depth higher order thinking skills of students in each cognitive domain (analysing, evaluating and creating). Thus, there are three specific objectives to determine a significance difference in pre-test and post-test scores between the control and the treatment groups. For instances, (i) To investigate whether there is a significance difference for pre-test and post-test between control and treatment groups; (ii) To investigate whether there is a significance difference between pre-test and post-test for the control and treatment groups; (iii) To analyse the higher order thinking skills of students for each cognitive domain (analysing, evaluating and creating) in control group and treatment groups. 


\section{METHODS}

A quantitative research method was used in this study. A quasi-experimental design was chosen, which Creswell (2005) defines as "procedures in quantitative research in which the investigator determines whether an activity or materials makes a difference in results for participants". Researcher involved two classes in the study. According to Campbell \& Stanley (1963), the quasi-experimental design is widely utilized designs in educational research. Trochim (2006), explained that in an educational setting, groups might be referred To schools or classrooms or known as intact group that are believe to be similar.

In this quasi-experimental design, the two groups were tested which are a control group and a treatment group. Two classes of same form (form 4 Art Stream students) were tested in this study: Class 4D (control group) was taught science with routine teaching, whereas class $4 \mathrm{~J}$ (treatment group) was taught using higher order thinking skills questions during teaching.

For this study, the treatment which was higher order thinking skills questions in teaching were carried out for ten lessons (1 hour 30 minutes per lesson). SciTHOTS were used as pre-test and posttest in this study. A pre-test for both groups were conducted before the treatment and a post-test at the end of the study. SciTHOTS consists of questions on higher cognitive domains in Bloom's taxonomy

\section{RESULTS AND DISCUSSION}

$\mathrm{H}_{\mathrm{o} 1}$ : There is no significance difference between the pre-test means score of control and treatment groups.

Table 1. Results of t-test and the Descriptive Statistics for pre-test between control and treatment groups

\begin{tabular}{llllllll}
\hline & Groups & $\mathrm{N}$ & Mean & $\begin{array}{l}\text { Std. } \\
\text { Deviation }\end{array}$ & $\begin{array}{l}\text { Std. } \\
\text { Mean }\end{array}$ & Error tvalue & pvalue \\
\hline $\begin{array}{l}\text { Control } \\
\text { Group }\end{array}$ & Pre-test & 30 & 4.39 & 2.42 & 0.44 & .28 .12 & 0.00 \\
\hline & Post-test & 30 & 45.11 & 7.55 & 1.38 & & \\
\hline
\end{tabular}

An independent-samples t-test was conducted to compare the means score of students' pre-test score for control and treatment groups. There was no significant difference in the means scores for pre-test control $(\mathrm{M}=4.39, \mathrm{SD}=2.42)$ and pre-test treatment group $(\mathrm{M}=4.00, \mathrm{SD}=2.54)$ for condition; $\mathrm{t}(58)=0.61$, $p=0.55$. These results show that students from control and treatment groups have similar abilities in answering the test questions in the beginning of the study. The means score around 4. indicates that students in both groups do not have much previous knowledge on the topic that was tested. Topic on body coordination was a new topic for them and was not taught earlier in any forms during science lessons, however there were some scientific terms like receptors, effectors and nerves were introduced earlier in science lessons.

$\mathrm{H}_{\mathrm{o} 2}$ : There is no significance difference between the post-test mean scores in control and treatment groups.

Table 2. Results of t-test and the Descriptive Statistics for post-test between control and treatment groups

\begin{tabular}{lllllll}
\hline Groups & $\mathrm{N}$ & Mean & Std. Deviation & Std. Error Mean & $\mathrm{t}$ value & $\mathrm{p} \mathrm{value}$ \\
\hline Control Group & 30 & 4.39 & 2.42 & 0.44 & 0.61 & 0.55 \\
Treatment Group & 30 & 4.00 & 2.54 & 0.46 & & \\
\hline
\end{tabular}

An independent-samples t-test was conducted to compare the means score of student's post-test score for control and treatment groups. There was a significant difference in the means scores for posttest control group $(\mathrm{M}=45.11, \mathrm{SD}=7.55)$ and post-test treatment group $(\mathrm{M}=60.00, \mathrm{SD}=8.15)$ for condition; $\mathrm{t}(58)=-7.33, \mathrm{p}=0.00$. These results indicate that the students in the treatment group perform better than control group in the SciTHOTS at the end of the lesson on the topic of body coordination when they were exposed to higher order thinking skills questions.

$\mathrm{H}_{\mathrm{o} 3}$ : There is no significance difference between the pre-test and post-test mean scores in control group.

Table 3. Results of t-test and the Descriptive Statistics for pre-test and post-test in control group

\begin{tabular}{|c|c|c|c|c|c|c|}
\hline \multicolumn{2}{|c|}{ GroupsN } & \multirow{2}{*}{$\frac{\text { Mean }}{4.39}$} & \multicolumn{2}{|c|}{$\begin{array}{ll} & \text { Std. } \\
\text { Std. } & \text { Error } \\
\text { Deviation } & \text { Mean } \\
\end{array}$} & value & $\begin{array}{l}\mathrm{p} \\
\text { value }\end{array}$ \\
\hline \multirow{2}{*}{$\begin{array}{l}\overline{\text { Contro }} \\
\text { Group }\end{array}$} & 30 & & 2.42 & 0.44 & \multirow{2}{*}{28.12} & \multirow{2}{*}{0.00} \\
\hline & 30 & 45.11 & 7.55 & 1.38 & & \\
\hline
\end{tabular}

An independent-samples t-test was conducted to compare the means score between the pre-test and 
post-test for control group. There was a significant difference in the means scores for pre-test $(M=4.39$, $\mathrm{SD}=2.42)$ and for post-test $(\mathrm{M}=45.11, \mathrm{SD}=7.55)$ for condition; $\mathrm{t}(58)=-28.12, \mathrm{p}=0.00$. These results show that the activities in the control group still able to prepare the students to reach the passing rate at 40 marks and with mean score 45.11 in the SciTHOTS. Students from the control group also benefited with the routine teaching.

$\mathrm{H}_{04}$ : There is no significance difference between the pre-test and post-test mean scores in treatment group.

Table 4. Results of t-test and the Descriptive Statistics for pre-test and post-test in treatment group

\begin{tabular}{|c|c|c|c|c|c|c|}
\hline & Groups N & N Mean & $\begin{array}{l}\text { Std. } \\
\text { n Deviation }\end{array}$ & $\begin{array}{l}\text { Std. } \\
\text { Error } \\
\text { Mean }\end{array}$ & $\begin{array}{l}\mathrm{t} \\
\text { value }\end{array}$ & $\begin{array}{l}\mathrm{p} \\
\text { value }\end{array}$ \\
\hline \multirow[t]{2}{*}{$\begin{array}{l}\text { Treatment } \\
\text { Group }\end{array}$} & $\begin{array}{l}\text { Pre- } \\
\text { test }\end{array}$ & 304.00 & 2.54 & 0.46 & \multirow{2}{*}{35.92} & \multirow{2}{*}{0.00} \\
\hline & $\begin{array}{l}\text { Post- } \\
\text { test }\end{array}$ & 3060.00 & 08.15 & 1.49 & & \\
\hline
\end{tabular}

An independent-samples t-test was conducted to compare the means score between the pre-test and post-test for treatment group. There was a significant difference in the means scores for pre-test $(M=4.00$, $\mathrm{SD}=2.54)$ and for post-test $(\mathrm{M}=60.00, \mathrm{SD}=8.15)$ for condition; $\mathrm{t}(58)=-35.92, \mathrm{p}=0.00$. These results indicate that students able to perform better on SciTHOTS at the end of the lesson on the topic of body coordination with teachers' posing higher order thinking skills questions. The mean score 60.00 indicates that students' performance in SciTHOTS were above than the passing rate at 40 marks.

$\mathrm{H}_{05}$ : There is no significance difference in posttest scores for cognitive domain (analysing) between control and treatment groups.

Table 5. Results of t-test and the Descriptive Statistics for post-test for cognitive domain (analysing) between control and treatment groups

\begin{tabular}{cclll}
\hline & & $\begin{array}{l}\text { Std. } \\
\text { Groups }\end{array}$ & $\begin{array}{l}\text { Std. } \\
\text { Error }\end{array}$ & $\begin{array}{l}\mathrm{t} \\
\text { value value }\end{array}$ \\
\hline AnalysisControl & 3015.942 .83 & 0.52 & \multirow{2}{*}{-4.49} & 0.00 \\
\cline { 2 - 5 } & Treatment3019.783.73 & 0.68 & & \\
\hline
\end{tabular}

An independent-samples t-test was conducted to compare the means score of post-test; students' higher order thinking skills in cognitive domain (analysing) between control and treatment groups.
There was a significant difference in the means scores for control group $(\mathrm{M}=15.94, \mathrm{SD}=2.83)$ and for treatment group $(\mathrm{M}=19.78, \quad \mathrm{SD}=3.73)$ for condition: $\mathrm{t}(58)=-4.49, \mathrm{p}=0.00$. These results indicate that students perform better in cognitive domain (analysing) in treatment group compared to control group in the SciTHOTS.

$\mathrm{H}_{\mathrm{ob}}$ : There is no significance difference in posttest scores for cognitive domain (evaluating) between control and treatment groups.

Table 6: Results of t-test and the Descriptive Statistics for post-test for cognitive domain (evaluating) between control and treatment groups

\begin{tabular}{|c|c|c|c|c|c|c|}
\hline Groups & $\mathrm{N}$ & Mean & $\begin{array}{l}\text { Std. } \\
\text { Deviation }\end{array}$ & $\begin{array}{l}\text { Std. } \\
\text { Error } \\
\text { Mean }\end{array}$ & $\begin{array}{l}\mathrm{t} \\
\text { value }\end{array}$ & $\begin{array}{l}\mathrm{p} \\
\text { value }\end{array}$ \\
\hline$\overline{\text { EvaluatingControl }}$ & 30 & 15.72 & 3.32 & 0.61 & \multirow{2}{*}{-5.26} & \multirow[b]{2}{*}{0.00} \\
\hline Treatmen & $t_{30}$ & 20.67 & 73.93 & 0.72 & & \\
\hline
\end{tabular}

An independent-samples t-test was conducted to compare the means score of post-test; students' higher order thinking skills in cognitive domain (evaluating) between control and treatment group. There was a significant difference in the means scores for control group $(\mathrm{M}=15.72, \mathrm{SD}=3.32)$ and for treatment $(\mathrm{M}=20.67, \mathrm{SD}=3.92)$ for condition; $\mathrm{t}$ $(58)=-5.26, p=0.00$. These results indicate that students perform better in cognitive domain (evaluating) in treatment group compared to control group in the SciTHOTS.

$\mathrm{H}_{07}$ : There is no significance difference in posttest scores for cognitive domain (creating) between control and treatment groups.

Table 7. Results of t-test and the Descriptive Statistics for post-test for cognitive domain (creating) between control and treatment groups

\begin{tabular}{|c|c|c|c|c|c|}
\hline Groups & $\mathrm{N}$ & $\begin{array}{l}\text { Std. } \\
\text { Mean Deviation }\end{array}$ & $\begin{array}{l}\text { Std. } \\
\text { Error } \\
\text { Mean }\end{array}$ & t & $\begin{array}{l}\mathrm{p} \\
\text { value }\end{array}$ \\
\hline CreateControl & 30 & 13.444 .42 & 0.81 & \multirow{2}{*}{-5.26} & \multirow{2}{*}{0.00} \\
\hline Treatmer & $\mathrm{t} 30$ & 19.564 .65 & 0.85 & & \\
\hline
\end{tabular}

An independent-samples t-test was conducted to compare the means score of post-test; students' higher order thinking skills in cognitive domain (creating) between control and treatment groups. 
There was a significant difference in the means scores for control group $(\mathrm{M}=13.44, \mathrm{SD}=4.42)$ and for treatment group $(\mathrm{M}=19.56, \mathrm{SD}=4.65)$ for condition; $\mathrm{t}(58)=-5.26, \mathrm{p}=0.00$. These results indicate that students perform better in cognitive domain (creating) in treatment group compared to the control group in the SciTHOTS.

The results of this research indicate that the students perform better in SciTHOTS when they were exposed to the teacher's higher order thinking skills questions compared to students in the routine teaching group. From the results, it shows that there is a significant impact on students' achievement on SciTHOTS when the teacher adds the questions during classroom instructions. According to Soleimani, H and Kheiri, S (2016), students score higher on test when incorporating higher levels of Bloom's Taxonomy through questioning thus making them to be the better problem solvers and the critical thinkers.

The students' improvement in SciTHOTS indicate that the students engaged in critical thinking such as providing reasoning for certain perspectives, problem solving, categorizing, analysing and deep learning of thinking occurs. Such cognitive opportunities can be promoted by higher order questions (Chen.M (2016). This practice may enable students to perform better in the SciTHOTS for the analysing domain in the treatment group. According to Freahat \& Smadi (2014) higher-level questions promote critical thinking ability and skills. Critical thinking such as able to analyse influenced students test achievement.

This opportunity may also increase their abilities to judge, or make decision or to discriminate on the issues discussed. Hence, students able to perform better in SciTHOTS on evaluating domain for treatment group. According to Bloom (1956), instructional questions promote students' cognitive processes at different complexity and levels. Thus, evaluating scientific knowledge can be promoted through higher order thinking questions.

\section{CONCLUSIONS}

From all of the findings and results of the research, it is found that the students from the treatment group performed better than the control group in SciTHOTS. This case showed that the students could answer questions of higher order thinking skills better when they were exposed to teacher's higher order thinking skills question during classroom instructions. Besides that, students in the treatment group could able to answer questions for each cognitive domain such as analysing, evaluating, and creating better then students in the control group.

Rowe (1974), and Tobin (1986) provide evidence that question-asking behaviour of teachers may be an important interceding variable in the relationship between higher-level questioning and higher-level thinking. This finding also supports Criswell and Criswell (2004) explanations, "to generate higher level thinking teachers must provide questions that require students to analyse, synthesize, and evaluate". Hence, it is important for teachers to include higher order thinking skills questions during classroom instruction especially during science lessons. This is because science teachers' have more opportunities to include higher order thinking skills in their questions such as questions that need students to differentiate, organise, attribute, construct, criticise, generate, plan, produce, and make decision. Students need these skills to survive in the ever changing and fast pace economy.

\section{REFERENCES}

Bloom, B. S. (Ed.) (1956). Taxonomy of educational objectives: The classification of educational goals, handbook I: cognitive domain. New York, NY: Longman.

Campbell, D. T., \& Stanley, J. C. (2015). Experimental and quasi-experimental designs for research. Ravenio Books.

Chen, M. H. (2016). Theoretical framework for integrating higher-order thinking into L2 speaking. Theory and Practice in Language Studies, 6(2), 217.

Chin, C. (2006). Classroom interaction in science: Teacher questioning and feedback to students' responses. International journal of science education, 28(11), 1315-1346.

Chin, C. (2007). Teacher questioning in science classrooms: Approaches that stimulate productive thinking. Journal of research in Science Teaching, 44(6), 815-843.

Criswell, J. R., \& Criswell, S. J. (2004). Asking essay questions: Answering contemporary needs. Education, 124(3), 510-517.

Creswell, J. W., (2005). Educational research: Planning, conducting, and evaluating quantitative and qualitative research (2nd ed.). Upper Saddle River, NJ: Pearson

Freahat, N. M., \& Smadi, O. M. (2014). Lower-order and higher-order reading questions in secondary and university level EFL textbooks in jordan. Theory and Practice in Language Studies, 4(9), 1804-1813. 
Hurd, P. D. (1998). Scientific literacy: New minds for a changing world. Science education, 82(3), 407-416

Ministry of Education, Malaysia. (2013). Malaysia Education Blue-print 2013: Preliminary Report 2013-2025. Retrieved 10 March, 2017, from http://www.moe.gov.my/images/dasar-

$\mathrm{kpm} /$ articlefile_file_003108.pdf

Ong, K. K. A., Hart, C. E., Chen, P. K. (2016). Promoting Higher-Order Thinking Through Teacher Questioning: A Case Study of a Singapore Science Classroom. New Waves, 19(1), 1.

Redfield, D. L. \& Rousseau, E. W. (1981). A metaanalysis of experimental research on teacher questioning behavior. Review of Educational Research. 51(2), 237-245.

Rowe, M. B. (1974). Wait-time and rewards as instructional variables, their influence on language, logic, and fate control: Part one-wait-time. Journal of research in science teaching, 11(2), 81-94.

Soleimani, H., \& Kheiri, S. (2016). An evaluation of TEFL postgraduates' testing classroom activities and assignments based on bloom's revised taxonomy. Theory and Practice in Language Studies, 6(4), 861869.

Tajudin, N.A.M. and Chinnappan, M., (2016). The Link between Higher Order Thinking Skills, Representation and Concepts in Enhancing TIMSS Tasks. International Journal of Instruction, 9(2),.199-214.

Tobin, K. (1986). Effects of teacher wait time on discourse characteristics in mathematics and language arts classes. American Educational Research Journal, 23(2), 191-200.

Tofade, T., Elsner, J., \& Haines, S. T. (2013). Best practice strategies for effective use of questions as a teaching tool. American journal of pharmaceutical education, 77(7), 155.

Trochim, W. M. K. (2006). The Non-equivalent Groups Design. Retrieved from http://www.socialresearchmethods.net/kb/quasnegd.p hp. 